\section{DISTRIBUTION OF THE REGAL PARACHUTE SPIDER PoECILOTHERIA REgALIS POCOCK, 1899}

\author{
Sanjay Molur 1,2,3, B.A. Daniel ${ }^{1,4}$ and Manju Siliwal ${ }^{2,5}$ \\ ${ }^{1}$ Zoo Outreach Organisation, ${ }^{2}$ Wildlife Information \& Liaison \\ Development Society \\ 29-1, Bharathi Colony, Peelamedu, Coimbatore, Tamil Nadu 641004, \\ India \\ Email: ${ }^{3}$ herpinvert@vsnl.com, ${ }^{4}$ icinsa@vsnl.net, \\ 5 manju@zooreach.org
}

(web supplement 1667i)

The Regal Parachute Spider Poecilotheria regalis Pocock, 1899 is one of the 14 described large-bodied parachute spiders of the family Theraphosidae restricted to peninsular India and Sri Lanka, with seven described species each from the two countries. Although large in size, the group of parachute spiders is very poorly studied in the wild, but are sought after by pet traders in America and Europe. It is apparent that the community of pet traders/ hobbyists know more about these spiders than the arachnological community in the two countries. This was evident when we conducted a questionnaire survey in 1999/2000 amongst more than 250 biologists and arachnologists in India and Sri Lanka. Only four of the respondents had actually seen such a spider in the wild, while most respondents had not even heard of such spiders! To understand the distribution, taxonomy and basic knowledge on this group of spiders in India, a project was initiated in 2000, whereby information on distribution, natural history, habitat, threats and folklore on Indian theraphosids was gathered by the Wildlife Information \& Liaison Development (WILD) Society and Zoo Outreach Organisation (ZOO) along with a group of collaborators.

Poecilotheria regalis, according to previous reports, was recorded from Arakkonam (close to Chennai) and later located in a few localities in the Western Ghats, in Matheran, Dahanu, Coorg, Nilgiris, Annamalais and outside of the Western Ghats in Mysore and Bangalore (Pocock, 1899, 1900; Gravely, 1915; Smith \& Kirk, 2001). P. regalis was first described from Arakkonnam, where it was found in the locomotive timber brought from Eastern Ghats (Pocock, 1900).

Questionnaire surveys were conducted along with visiting different museums for studying collections. Field surveys were conducted in certain parts of southern India in Maharashtra, Karnataka, Andhra Pradesh, Tamil Nadu and Kerala. Visible clues were used to determine the presence of theraphosid spiders in random transects and trails in different habitats throughout the study areas. Tree burrows were examined for direct evidence of the spider or for indirect evidence through silk lining and discarded exuviae. Once a spider was located, photographs of the animal and habitat were taken; when possible the animal was teased out of the tree hole for identification and released after examination. All exuviae found during the study were collected.
Species identifications were based on Pocock $(1899,1900)$, and Smith and Kirk (2001). Morphological characters such as ventral and dorsal leg patterns were recorded, measurements were taken of the live specimen and of exuviae using Mitutoyo ${ }^{\mathrm{TM}}$ vernier calipers. Detailed notes on taxonomic and habitat characteristics will be presented in a separate paper.

During the study $P$. regalis (Image $1^{\mathrm{w}}$ )was, relatively, the most commonly sighted parachute spider. In the present study it was recorded from 13 localities in southern India, and is until now known from 22 localities including old published information (Table 1). Information on distribution from other sources such as from pet traders and collectors, and from foreign publications of the Tarantula Societies is not available, hence not included here. This species is one of the easiest parachute spiders to identify because of the broad, pale, pink or pinkishorange epigynal band on the ventral surface of the abdomen (Image $2^{\mathrm{w}}$ ). Several related species exhibit paler areas in the same region, but the band is not continuous or as distinctive as in this species. Additional characters such as leg patterns, stridulatory organ structure and dorsal markings as defined by Smith and Kirk (2001) make the identification of this species simpler.

This species was recorded in various wooded habitats. Most of the sightings were from medium- to old-growth teak plantations, while some were in primary forests and only one specimen each in severely degraded forest and banana plantation. We believe that the ease of sighting this species in medium-to old-growth teak plantations is due to lack of dense undergrowth and the ease of traversing through and searching tree holes. Due to the extremely sensitive nature of these spiders (Their tactile senses being very sharp, they retreat into the deep recesses of the tree holes when the vegetation around the tree is disturbed.), our sighting of these spiders in mixed vegetation forests, either primary or secondary, was minimum. In the case of degraded forests, where one specimen was observed, the juvenile was in a very shallow tree hole, concealed more from camouflage than from the depth of the burrow. This spider, although seems to have adapted to changing habitats better compared to other species, it does not seem to do well in degraded habitats. Its presence in degraded areas is almost negligible.

Males were more commonly sighted than females. While the females keep to very small ranges around the tree holes they establish as their own, the males migrate long distances. Migrating males, especially during the rainy season are usually sighted in human dwellings within the area. In some instances we also noticed juveniles in living accommodations with a few legs missing. This could be due to competition between siblings in a nest, resulting in cannibalism.

Earlier records of $P$. regalis from various locations in the Western Ghats by collectors, field experts and taxonomists in the early $20^{\text {th }}$ century is fairly well supported by the different locations we were able to record their presence. As this project involved many individuals surveying different areas, information on presence of $P$. regalis through documented evidence such as

${ }^{w}$ See the web supplement on www.zoosprint.org for images of the spider. 
1. Turanmal

2. Dahanu ( $\left.19^{\circ} 58^{\prime} \mathrm{N} \& 72^{\circ} 44^{\prime} \mathrm{E}\right)$

3. Matheran $\left(18^{\circ} 59^{\prime} \mathrm{N} \& 73^{\circ} 16^{\prime} \mathrm{E}\right)$

4. Amba Valley

5. Coorg $\left(12^{\circ} 25^{\prime} \mathrm{N} \& 75^{\circ} 45^{\prime} \mathrm{E}\right)$

6. Mysore $\left(13^{\circ} 30^{\prime} \mathrm{N} \& 76^{\circ} 00^{\prime} \mathrm{E}\right)$

7. Theppakadu, Mudumalai $\left(11^{10} 37^{\prime} \mathrm{N} \& 76^{\circ} 34^{\prime} \mathrm{E}\right)$

8. Masinagudi

9. Nilgiri Hills

10. Avanashi $\left(11^{0} 12^{\prime} \mathrm{N} \& 77^{\circ} 17^{\prime} \mathrm{E}\right)$

11. Moongilpallam, Anaikatti

12. Puttapathi, Siruvani

13. Anamalai Hills, South of Palghat Gap

14. Sengottai ( $\left.8^{\circ} 58^{\prime} \mathrm{N} \& 77^{\circ} 16^{\prime} \mathrm{E}\right)$

15. Bangalore $\left(12^{\circ} 59^{\prime} \mathrm{N} \& 77^{\circ} 35^{\prime} \mathrm{E}\right)$

16. Arakkonam $\left(13^{\circ} 06^{\prime} \mathrm{N} \& 79^{\circ} 40^{\prime} \mathrm{E}\right)$

17. Madanapalle $\left(13^{\circ} 33^{\prime} \mathrm{N} \& 78^{\circ} 30^{\prime} \mathrm{E}\right)$

18. Biarapur Cheruvu

19. Thummalabailu (15057'20"N \& 78055'20"E) , , ,

20. Shikharam (1603'10"N \& 78051'19"E)

21. Sunipenta (16048'17"N \& 78054'19"E)

22. Paldhara Panchdhara $\left(16^{\circ} 03^{\prime} \mathrm{N} \& 78^{\circ} 53^{\prime} \mathrm{E}\right)$

23. Nandyal - Giddalur Road (15025'49.9"N \& 78045'59.9"E)
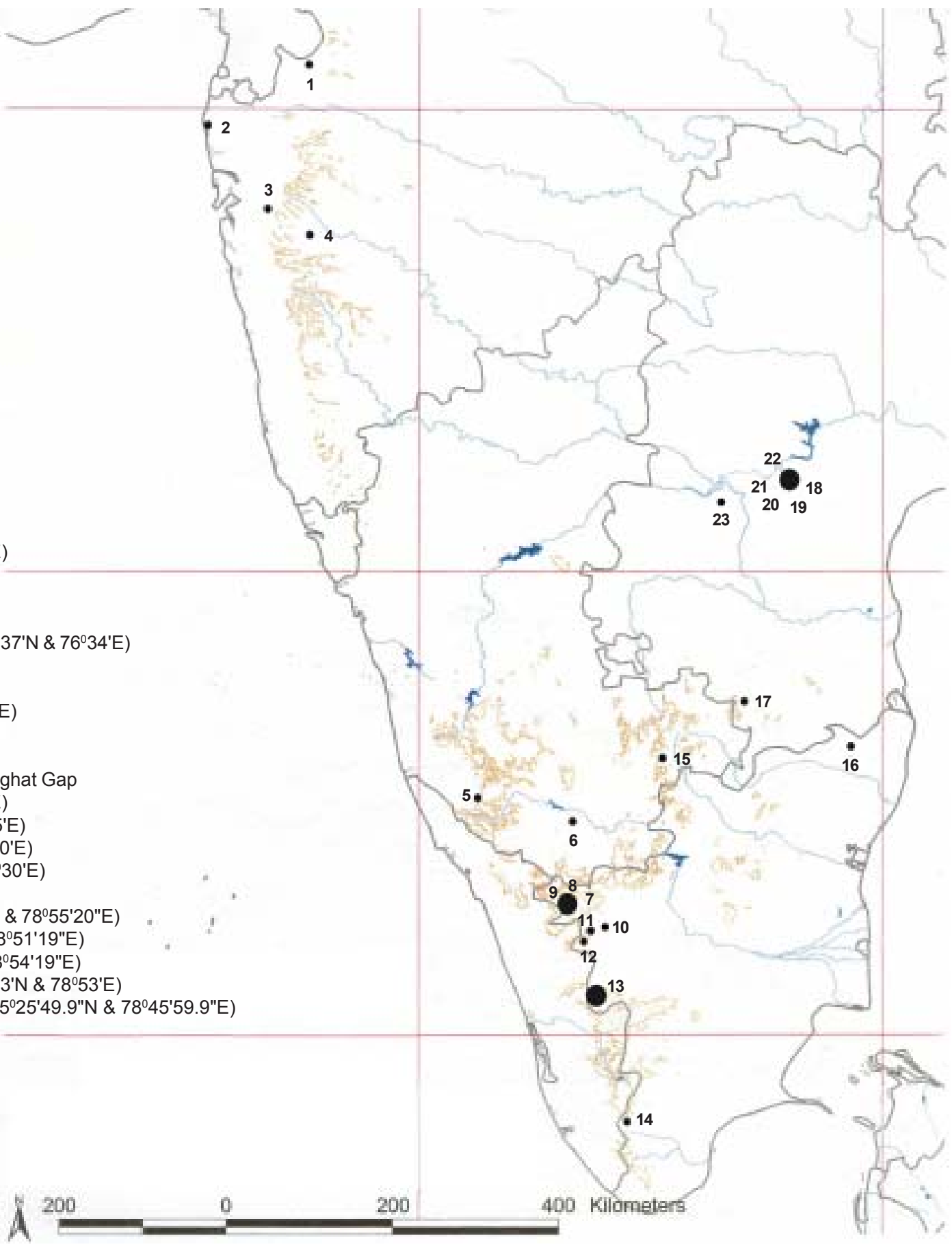

Figure 1. Confirmed records of Poecilotheria regalis in southern India.

photographs were considered in determining distribution. Evidence of its occurrence in the Eastern Ghats was confirmed as this species was spotted in four different localities within the Nallamalai range in Andhra Pradesh.

The altitudinal range of occurrence of this species is between 250 and $1800 \mathrm{~m}$. In one instance a mature female was found in a banana plantation in Avinashi, 40km from Coimbatore, far from any vegetation. Subsequently, however, we have not sighted or heard about such occurrences. P. regalis is probably also present in Castle Rock, Anshi Ghats and the forests of northwestern Karnataka and southwestern Maharashtra, although conclusive evidence is required.

There is a mention of this species by Gravely (1915) as occurring to the south of Palghat Gap and by Gravely (1935) in Shenkottah, Travancore (= Sengottai, Tamil Nadu) and Madanapalle in Chittoor District of Andhra Pradesh. However, in our studies, 
Table 1. Distributional records of P. regalis from publications and present study (until September 2004).

\begin{tabular}{|c|c|c|c|c|c|}
\hline Locality & Date of sighting & Found on & No. / Sex & Habitat & Source(s) \\
\hline \multicolumn{6}{|l|}{ Andhra Pradesh } \\
\hline 1. Madanapalle & Before 1935 & Unknown & $1 \mathrm{U}$ & Unknown & Gravely, 1935 \\
\hline 2. Nandyal-Giddalur Road & Sep. 2001 & Red bark Tree & $1 \mathrm{M}$ & Degraded and extensively lopped DDF & Present study \\
\hline 3. Biarapur Cheruvu, NSTR & Jul 2002 & Tamarindus indicus & $1 \mathrm{~F}$ & DDF & Rao et al. (2004); present study \\
\hline 4. Thummalabailu, NSTR & Aug. 2002 & Zizyphus oenoplia & $1 \mathrm{M}^{*}$ & DDF & Rao et al. (2004); present study \\
\hline 5.Shikharam, NSTR & \multicolumn{2}{|c|}{ Sep. 2002, Jul. 2003 Wall } & $1 \mathrm{M}^{*}, 1 \mathrm{M}^{*}$ & Surrounded by DDF & Rao et al. (2004); present study \\
\hline \multicolumn{2}{|c|}{ 6. Paldhara Panchdhara, NSTR June 2003} & Ficus glomerata & $2 \mathrm{~F}+9 \mathrm{~J}$ & Sacred Grove, Evergreen patch in DDF & C. Srinivasulu, Present study \\
\hline \multicolumn{6}{|l|}{ Tamil Nadu } \\
\hline 7. Arakkonam & Late 1890 s & \multicolumn{2}{|c|}{ Locomotive timber $1 \mathrm{~F}$} & \multicolumn{2}{|c|}{$\begin{array}{l}\text { Although found in locomotive timber at Pocock, } 1899 \\
\text { Arakkonam Railway Station, this specimen could have come from some } \\
\text { Eastern Ghats forest logged for timber and transported by rail. }\end{array}$} \\
\hline 8. Nilgiri Hills & Late 1890 s & Unknown & $1 \mathrm{~F}$ & Unknown & Pocock, 1900 \\
\hline 9. Sengottai & Before 1935 & Unknown & $1 U$ & Unknown & Gravely, 1935 \\
\hline 10. Puttapathi, Siruvani & Jul. 1997, Sep. 2000 & 0 Tectona grandis & $1 \mathrm{~F} 2 \mathrm{~F}^{*}+37 \mathrm{~J}^{*}$ & Teak plantation & Ganesh Kumar, present study \\
\hline 11. Avinashi & Mar. 2002 & Musa sp. hybrid & $1 \mathrm{~F}$ & Banana plantation & Ganesh Kumar, present study \\
\hline 12. Masinagudi & June 2002 & Tectona grandis & $1 \mathrm{M}^{*}$ & DDF with teak plantation & Subramanyam, present study \\
\hline 13. Theppakadu, Mudumalai & October 2002 & Wall & $1 U^{*}$ & Inside house, surrounded by DDF & Subramanyam, present study \\
\hline 14. Moongilpallam, Anaikatti & Aug. 2003 & Wall & $1 \mathrm{M}^{*}$ & $\begin{array}{l}\text { Inside hostel room, Surrounded by DDF, } \\
\text { and scrub land with very few trees. }\end{array}$ & S. Bhupathy, present study \\
\hline \multicolumn{6}{|l|}{ Karnataka } \\
\hline 15. Mysore & Unknown & Unknown & $1 \mathrm{U}$ & Unknown & Smith \& Kirk (2001); \\
\hline 16. Coorg & Late 1890 s & Unknown & $1 \mathrm{M}$ & Unknown & Pocock, 1900 \\
\hline 17. Bangalore & $\begin{array}{l}\text { Before 1915; } \\
2000\end{array}$ & $\begin{array}{l}\text { Unknown } \\
\text { Tree buttress }\end{array}$ & $\begin{array}{l}1 \mathrm{M} \\
1 \mathrm{U}\end{array}$ & $\begin{array}{l}\text { Unknown } \\
\text { Unknown }\end{array}$ & $\begin{array}{l}\text { Gravely, 1915; } \\
\text { Madhusudan \& Narendran, } \\
\text { present study }\end{array}$ \\
\hline \multicolumn{6}{|l|}{ Maharashtra } \\
\hline 18. Matheran & Late 1890s & Unknown & Unknown & Unknown & Pocock, 1900 \\
\hline 19. Dahanee, Thane & Late 1890s & Unknown & $\mathrm{F}$ & Unknown & Pocock, 1900 \\
\hline 20. Amba Valley & Oct. 2002 & Ficus racemosa & $1 \mathrm{~F}^{*}$ & DDF with teak plantation & Sanjay Thakur, present study \\
\hline 21. Turanmal & Sep. 2003 & Terminalia alata & $1 \mathrm{~F}^{*}$ & DDF with teak plantation & Sanjay Thakur, present study \\
\hline $\begin{array}{l}\text { Kerala / Tamil Nadu } \\
\text { 22. Annamalai Hills }\end{array}$ & Before 1915 & Unknown & $1 \mathrm{~F}$ & Unknown & Gravely, 1915 \\
\hline
\end{tabular}

we did not come across this species south of the Palghat Gap and we presume that it is sporadically distributed in the Western Ghats, the Eastern Ghats and in some well-wooded areas of the Deccan Plateau. We also reexamined Cheeran and Nagaraj's (1997) record from Vazhani forest in Kerala (south of Palghat Gap) and found that the spider had been wrongly identified as $P$. regalis. Although a relatively common species compared to other parachute spiders, the patchy distribution of this species (like others) makes it difficult to sight unless either thorough surveys are conducted, or by sheer coincidence when a migrating male is sighted in and around human habitation. As the Map (Figure 1) indicates, the species is only sighted in a few locations, but could exist in other areas in between in both the Western and the Eastern Ghats. Studies are required to establish their range to evaluate contiguity of distribution.

\section{REFERENCES}

Cheeran, J.V. and B.N. Nagaraj (1997). Occurrence of the great Indian spider Ischnocolus (= Poecilotheria) regalis in Vazhachal forest,
Kerala. Zoos' Print 12(1): 28-29.

Gravely, F.H. (1915). Notes on Indian mygalomorph spiders. Records of the Indian Museum Calcutta 11: 257-287.

Gravely, F.H. (1935). Notes on Indian mygalomorph spiders. II. Records of the Indian Museum Calcutta 37: 69-84.

Molur, S. and M. Siliwal (2004). Common names of South Asian theraphosid spiders (Araneae: Theraphosidae). Zoos' Print Journal 19(10): 1657-1662.

Pocock, R.I. (1899). The genus Poecilotheria: its habits, history and species. The Annals and Magazine of Natural History (7) 3: 82-96.

Pocock, R.I. (1900). Great Indian Spiders. The Genus Poecilotheria: its Habits, History and Species. Journal of the Bombay Natural History Society 13: 121-133.

Rao, K.T., M.P. Raju, I.S.R. Krishna, S.M.M. Javed, M. Siliwal and C. Srinivasulu (2004). Record of Poecilotheria regalis Pocock, 1899 from Nallamala Hills, Eastern Ghats, Andhra Pradesh. Zoos' Print Journal 19(10): 1668

Smith, A.M. and P. Kirk (2001). A field Guide on the theraphosid spiders of Indian and Sri Lanka particularly the Genus Poecilotheria. (unpublished). 